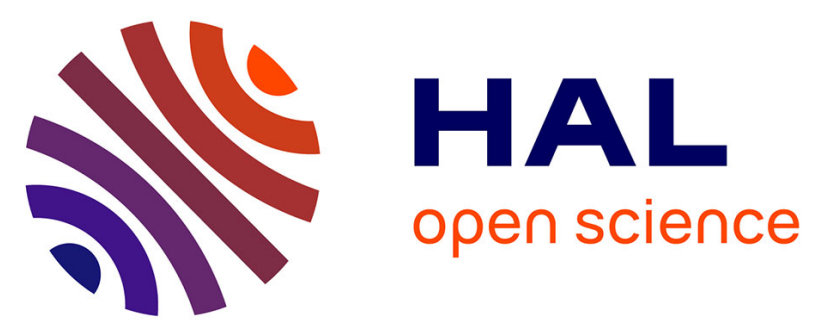

\title{
Electrografting of Diazonium-Functionalized Polyoxometalates: Synthesis, Immobilisation and Electron-Transfer Characterisation from Glassy Carbon
}

Corentin Rinfray, Guillaume Izzet, Jean Pinson, Sarra Gam Derouich, Jean-Jacques Ganem, Catherine Combellas, Frédéric Kanoufi, Anna Proust

\section{To cite this version:}

Corentin Rinfray, Guillaume Izzet, Jean Pinson, Sarra Gam Derouich, Jean-Jacques Ganem, et al.. Electrografting of Diazonium-Functionalized Polyoxometalates: Synthesis, Immobilisation and Electron-Transfer Characterisation from Glassy Carbon. Chemistry - A European Journal, 2013, 19 (41), pp.13838-13846. 10.1002/chem.201302304 . hal-01237471

\section{HAL Id: hal-01237471 \\ https://hal.science/hal-01237471}

Submitted on 3 Apr 2017

HAL is a multi-disciplinary open access archive for the deposit and dissemination of scientific research documents, whether they are published or not. The documents may come from teaching and research institutions in France or abroad, or from public or private research centers.
L'archive ouverte pluridisciplinaire HAL, est destinée au dépôt et à la diffusion de documents scientifiques de niveau recherche, publiés ou non, émanant des établissements d'enseignement et de recherche français ou étrangers, des laboratoires publics ou privés. 


\title{
Electrografting of Diazonium Functionalized Polyoxometalates: Synthesis, Immobilization and Electron Transfer Characterization from Glassy Carbon
}

\author{
Corentin Rinfray, ${ }^{\text {a }}$ Guillaume Izzet, ${ }^{\text {a }}$ Jean Pinson, ${ }^{\text {b }}$ Sarra Gam Derouich,, a, Jean- \\ Jacques Ganem, ${ }^{c}$ Catherine Combellas, ${ }^{\mathrm{b}}$ Frédéric Kanoufi, ${ }^{\mathrm{b}} *$ and Anna Proust ${ }^{\mathrm{a}}$ * \\ a Institut Parisien de Chimie Moléculaire, UMR CNRS 7201 - UPMC Univ Paris 06, \\ Université Pierre et Marie Curie, 4 place Jussieu, case courrier 42, F-75252 Paris Cedex 05, \\ France. E-mail : anna.proust@upmc.fr \\ ${ }^{\mathrm{b}}$ Physicochimie des Electrolytes, Colloides et Sciences Analytiques, UMR CNRS 7195- \\ ESPCI ParisTech, 10 rue Vauquelin, 75231 Paris Cedex 05, France. E-mail : \\ frederic.kanoufi@espci.fr \\ ${ }^{c}$ Institut des NanoSciences de Paris, UMR CNRS 7588 - UPMC Univ Paris 06, Université \\ Pierre et Marie Curie, 4 place Jussieu, case courrier 840, F-75252 Paris Cedex 05, France
}

ABSTRACT: Polyoxometalates (POMs) are attractive candidates for the rational design of multi-level charge storage materials since they display reversible multi-step reduction processes in a narrow range of potentials. The functionalization of POMs allows for their integration in hybrid CMOS/molecular devices, provided that a fine control of their immobilization on various substrates can be achieved. Owing to the wide applicability of the diazonium route to surface modification, a functionalized Keggin-type POM $\left[\mathrm{PW}_{11} \mathrm{O}_{39}\{\mathrm{Ge}(p\right.$ $\left.\left.\left.\mathrm{C}_{6} \mathrm{H}_{4}-\mathrm{CC}-\mathrm{C}_{6} \mathrm{H}_{4}-\mathrm{N}_{2}^{+}\right)\right\}\right]^{3-}$ bearing a pending diazonium group was prepared and subsequently covalently anchored onto a glassy carbon electrode. Electron transfer with the immobilized POM was thoroughly investigated and compared to that of the free POM in solution.

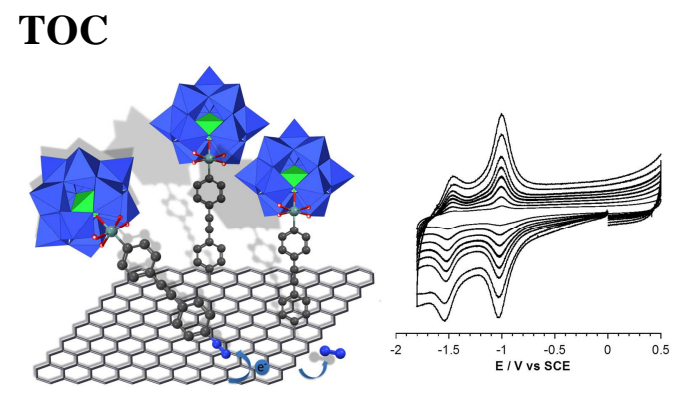




\section{INTRODUCTION}

In the course of the unceasing downscaling of microelectronic components, a midterm hybrid approach, mixing complementary metal oxide semiconductor (CMOS) technology and molecules, is emerging, especially for the development of dynamic random access memories (DRAM) or modified transistors. ${ }^{1,2}$ Main issues associated with component size decrease, such as excessive current leakage and device-to-device variation due for example to inhomogeneous silicon doping, are expected to be addressed with the incorporation of molecules having intrinsic non size-dependent properties and discrete electronic states. This hybrid CMOS / molecular approach is an intermediate step towards allmolecular electronics, which is indeed appealing but still far from practical applications., The potential of porphyrins as charge storage molecules has been thoroughly investigated. ${ }^{5-7}$ Like porphyrins, polyoxometalates (POMs) have intrinsic features that could prove valuable in this context. POMs form a unique class of soluble molecular oxides with a great diversity in terms of structure, size, redox behaviour and they display a wide range of applications making them promising building blocks for molecular materials chemistry. ${ }^{8}$ They are often viewed as the missing link between extended metal oxides and molecular oxides. ${ }^{9}$ Many POMs display several discrete redox states in a narrow range of potentials, ${ }^{10}$ which should give access to multi-level memories. The limited structural reorganization accompanying POM reduction processes and the delocalization of the added electrons over part or whole of the POM skeleton account for the reversibility of these processes and are strong assets for a long term stability upon writing/reading cycles. While porphyrins have been assembled in ptype components, POMs could provide n-type counterparts. The remarkable diversity of their molecular structures allows for a fine-tuning of their redox properties and more than two successive reduction states are often accessible with no need to elaborate complex architectures. Furthermore, as soluble species, POMs are relatively easy to handle and process and their robustness is compatible with high temperature and low pressure preparation methods used in microelectronics technology and would also ensure their longevity under operating conditions. POMs could thus provide a new class of robust electronic materials with a size downscaled to a few nanometres and multi-level redox states accessible in a unique component, both features attracting considerable attention.

In this context, and since the control of the orientation of the molecules and their density on the surface together with the longevity of the materials are key criteria, we favor the covalent immobilization of POMs rather than the self-assembly method although charge transport phenomena in Layer-by-Layer POM-based molecular junctions has been reported in 
the literature. ${ }^{11,12}$ Examples of covalent immobilization of POMs on surfaces are still scarce and often limited to Anderson and Lindqvist type POMs. ${ }^{1,13,14}$ While the redox properties of the Anderson anions are limited to those of the central hetero-metal, drain current and threshold voltage were found to be modulated in a pseudo metal-oxide-semiconductor fieldeffect transistor (MOSFET) modified by organo-imido functionalized Lindqvist anions. ${ }^{1}$ However, more redox versatility is expected by using the Keggin- and Dawson-series.

Our long-standing interest in the functionalization of $\mathrm{POMs}^{8}$ allows us to propose a variety of hybrid POM platforms in the Keggin- or Dawson-series, with tunable redox properties and adjustable reactive pending groups for surface anchorage. ${ }^{15,16}$ In a preliminary study, we have described the covalent grafting of a POM hybrid onto silicon wafers toward capacitive memories. ${ }^{15}$ In the herein contribution, we describe i) the efficient synthetic procedure of the new functionalized Keggin-type POM $\left[\mathrm{PW}_{11} \mathrm{O}_{39}\left\{\mathrm{Ge}\left(p-\mathrm{C}_{6} \mathrm{H}_{4}-\mathrm{CC}-\mathrm{C}_{6} \mathrm{H}_{4}-\right.\right.\right.$ $\left.\left.\left.\mathrm{N}_{2}^{+}\right)\right\}\right]^{3-}\left(\mathbf{K}_{\mathbf{G e}}\left[\mathbf{N}_{2}^{+}\right]\right)^{17}$ bearing a much simpler organic tether than the one of the previously described hybrid, ${ }^{15}$ ii) its covalent immobilization onto a glassy carbon electrode and, iii) its thorough electrochemical characterization once confined at the surface. The diazonium function was chosen because of its ability to graft to various substrates: ${ }^{18}$ i) by electrochemical ${ }^{19}$ or chemical reduction of the diazonium salt, ${ }^{20}$ ii) spontaneously on some reducing or non reducing materials, iii) photochemically in the presence of a photosensitizer, ${ }^{21}$ or iv) by irradiation of a charge transfer complex. ${ }^{22}$ Although the reaction generally leads to disordered multilayers, it is possible to obtain bonded monolayers, for example by i) control of the grafting conditions, ${ }^{23,24}$ ii) cleavage of multilayers, ${ }^{25,26}$ or iii) steric effects. ${ }^{27-29}$ Here, owing to the POM bulkiness, a grafted monolayer is expected.

\section{MATERIALS AND METHODS}

2.1. Materials and Characterization Techniques. Manipulation of all air sensitive compounds was carried out using standard high vacuum techniques. Tetrahydrofuran was distilled from sodium/benzophenone. Triethylamine was distilled from $\mathrm{CaH}_{2}$. Dimethylformamide was purchased stored under argon over molecular sieve. $\mathrm{K}_{7}\left[\mathrm{PW}_{11} \mathrm{O}_{39}\right] \cdot 14 \mathrm{H}_{2} \mathrm{O},{ }^{30}\left[\mathrm{Pd}\left(\mathrm{PPh}_{3}\right)_{2} \mathrm{Cl}_{2}\right]^{31}$ and 3,3-diethyl-1-(4-ethynylphenyl)triaz-1-ene ${ }^{32}$ were prepared according to published procedures. All other reagents were used as supplied. NMR spectra were recorded on a Bruker AvanceII 300 spectrometer equipped with a QNP probehead. ${ }^{1} \mathrm{H}$ chemical shifts are quoted as parts per million (ppm) relative to 
tetramethylsilane using the solvent signals as secondary standard ( $\mathrm{s}$ : singlet, d: doublet, $\mathrm{t}$ : triplet, q: quartet, sex: sextet, dt: doublet of triplets, m: multiplet) and coupling constants (J) are quoted in Hertz $(\mathrm{Hz}) .{ }^{31} \mathrm{P}$ chemical shifts are quoted relative to $85 \% \mathrm{H}_{3} \mathrm{PO}_{4}$.

IR spectra were recorded from $\mathrm{KBr}$ pellets on a Biorad FT 165 spectrometer.

ESI mass spectra were recorded using an LTQ Orbitrap hybrid mass spectrometer (Thermofisher Scientific, Bremen, Germany) equipped with an external ESI source operated in the negative ion mode. Spray conditions included a spray voltage of $3 \mathrm{kV}$, a capillary temperature maintained at $280^{\circ} \mathrm{C}$, a capillary voltage of $-30 \mathrm{~V}$ and a tube lens offset of $-90 \mathrm{~V}$. Sample solutions (10 pmol. $\left.\mu \mathrm{L}^{-1}\right)$ were infused into the ESI source by using a syringe pump at a flow rate of $180 \mu \mathrm{L} \cdot \mathrm{h}^{-1}$.

Elemental analyses were performed at the Institut de Chimie des Substances Naturelles, Gif sur Yvette, France.

Electrochemical studies were performed on an Autolab PGSTAT 100 work station (Metrohm) or a CH660 potentiostat (CH Instruments) using a standard 3-electrode setup. Working glassy carbon electrodes ( 2 and $3 \mathrm{~mm}$ diameter) were polished with $6 \mu \mathrm{m}$ diamond paste, sonicated in ethanol for $5 \mathrm{~min}$ and dried with an argon flow. Platinum wire and saturated calomel electrode (SCE) equipped with a double junction were used as auxiliary and reference electrodes respectively.

Rutherford Backscattering Spectrometry (RBS) was performed on the SAFIR beamline of ALTAÏS at the Laboratoire pour Analyses par Réactions Nucléaires. A $1.8 \mathrm{MeV} 4 \mathrm{He}^{+}$beam was collimated to give a current of $10 \mathrm{nA}$ in a $1 \times 1 \mathrm{~mm}^{2}$ beam spot at the sample surface, and scattered particles were detected with a conventional semiconductor detector placed at $165^{\circ}$ with respect to the incident beam direction. RBS spectra from consecutive measurements for $1 \mu \mathrm{C}$ of incident beam charge confirmed that the $\mathrm{W}$ signal was stable under the beam.

2.2. Synthesis of Trichloro(4-iodophenyl)germane. 1,4-diiodobenzene ( $5 \mathrm{~g}, 15.2 \mathrm{mmol})$ was dissolved in distilled THF $(30 \mathrm{~mL})$ under argon. The solution was cooled down to $-30{ }^{\circ} \mathrm{C}$, and isopropylmagnesium chloride $2.0 \mathrm{~mol}^{-1} \mathrm{~L}^{-1}$ solution in THF $(9.1 \mathrm{~mL}, 18.2 \mathrm{mmol})$ was added. After 3 hours at $-30{ }^{\circ} \mathrm{C}$ under stirring, the solution was cannulated to a $-30{ }^{\circ} \mathrm{C}$ solution of germanium(IV) chloride $(3.47 \mathrm{~mL}, 6.5 \mathrm{~g}, 30.4 \mathrm{mmol})$ in distilled THF $(20 \mathrm{~mL})$, and the mixture was allowed to warm to room temperature and stirred for another 24 hours. After evaporation of THF, the resulting product was distilled under reduced pressure with a Kugelrohr $\left(130{ }^{\circ} \mathrm{C}\right)$ to afford $1.5 \mathrm{~g}$ of colourless oil $(26 \%) . \delta_{\mathrm{H}}\left(300 \mathrm{MHz}, \mathrm{CDCl}_{3}\right) 7.95\left(\mathrm{dt},{ }^{3} \mathrm{~J}\right.$ 
$=8.5 \mathrm{~Hz},{ }^{4} \mathrm{~J}=2.0 \mathrm{~Hz}, 2 \mathrm{H}$, Ar- $\left.H\right), 7.48\left(\mathrm{dt},{ }^{3} \mathrm{~J}=8.5 \mathrm{~Hz},{ }^{4} \mathrm{~J}=2.0 \mathrm{~Hz}, 2 \mathrm{H}\right.$, Ar- $H$ ); elemental analysis for $\mathrm{C}_{6} \mathrm{H}_{4} \mathrm{GeCl}_{3} \mathrm{I}(\%)$ : calcd C 18.87, H 1.06; found C 19.12, H 1.06.

2.3. Synthesis of $\mathbf{T B A}_{4}\left[\mathbf{P W}_{11} \mathbf{O}_{39}\left\{\mathbf{G e}\left(\mathbf{C}_{6} \mathbf{H}_{4}\right) \mathbf{I}\right\}\right] \quad \mathbf{K}_{\mathbf{G e}}[\mathbf{I}] . \quad \mathrm{K}_{7}\left[\mathrm{PW}_{11} \mathrm{O}_{39}\right] \cdot 14 \mathrm{H}_{2} \mathrm{O} \quad(1,0 \mathrm{~g}$, $0.3 \mathrm{mmol})$ was dissolved in water $(10 \mathrm{~mL})$. A solution of trichloro(4-iodophenyl)germane $(0.18 \mathrm{~g}, 0.47 \mathrm{mmol})$ in DMF $(10 \mathrm{~mL})$ was added, and the cloudy mixture was stirred until clearness ( $c a 1$ hour). The solution was filtered, and tetrabutylammonium bromide (TBABr, $0.5 \mathrm{~g}, 1.6 \mathrm{mmol})$ was added. The white precipitate was filtered and washed with ethanol $(2 \mathrm{x}$ $20 \mathrm{~mL})$ and diethylether $(2 \times 20 \mathrm{~mL})$ to afford $1.1 \mathrm{~g}$ of a white powder $(92 \%) . \delta_{\mathrm{H}}(300 \mathrm{MHz}$, $\left.\mathrm{CD}_{3} \mathrm{CN}\right) 7.85\left(\mathrm{~d},{ }^{3} \mathrm{~J}=8.0 \mathrm{~Hz}, 2 \mathrm{H}, \operatorname{Ar}-H\right), 7.61\left(\mathrm{~d},{ }^{3} \mathrm{~J}=8.0 \mathrm{~Hz}, 2 \mathrm{H}, \operatorname{Ar}-H\right), 3.17(\mathrm{~m}, 32 \mathrm{H}, \mathrm{N}-$ $\left.\mathrm{CH}_{2}-\mathrm{CH}_{2}-\mathrm{CH}_{2}-\mathrm{CH}_{3}\right), 1.67$ (m, 32H, N-CH $\left.2-\mathrm{CH}_{2}-\mathrm{CH}_{2}-\mathrm{CH}_{3}\right), 1.43\left(\mathrm{sex},{ }^{3} \mathrm{~J}=7.5 \mathrm{~Hz}, 32 \mathrm{H}, \mathrm{N}-\right.$ $\left.\mathrm{CH}_{2}-\mathrm{CH}_{2}-\mathrm{CH}_{2}-\mathrm{CH}_{3}\right) 1.02\left(\mathrm{t},{ }^{3} \mathrm{~J}=7.5 \mathrm{~Hz}, 48 \mathrm{H}, \mathrm{N}-\mathrm{CH}_{2}-\mathrm{CH}_{2}-\mathrm{CH}_{2}-\mathrm{CH}_{3}\right) ; \delta_{\mathrm{P}}\left(121 \mathrm{MHz}, \mathrm{CD}_{3} \mathrm{CN}\right)$ -13.33; $\mathrm{m} / \mathrm{z}$ (ESI-), most intense peaks (\%): 738.3 (42) $[\mathrm{M}]^{4-}$ requires $738.8,984.7$ (100) $[\mathrm{M}+\mathrm{H}]^{3-}$ requires $985.0,1468.5(13)[\mathrm{M}-\mathrm{O}]^{2-}$ requires $1469.0,1597.7$ (13) $[\mathrm{M}+\mathrm{TBA}+\mathrm{H}]^{2-}$ requires 1598.6; IR (KBr pellet, $\left.\mathrm{cm}^{-1}\right) 2962(\mathrm{~m}), 2935$ (m), $2874(\mathrm{~m}), 1483(\mathrm{~m}), 1380(\mathrm{w})$, 1095 (m), 1074 (m), 964 (s), 887 (m), 811 (vs), 390 (m); elemental analysis for $\mathrm{C}_{70} \mathrm{H}_{148} \mathrm{GeIN}_{4} \mathrm{O}_{39} \mathrm{PW}_{11}(\%)$ : calcd C 21.43, H 3.80, N 1.43; found: C 21.13, H 3.79, N 1.46 .

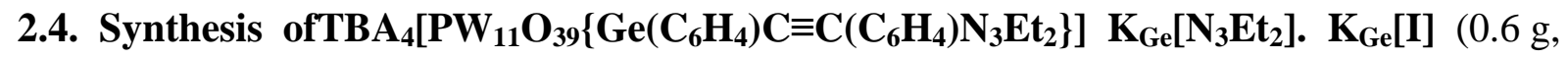
$0.15 \mathrm{mmol}), \quad 3,3$-diethyl-1-(4-ethynylphenyl)triaz-1-ene $\quad(62.0 \mathrm{mg}, \quad 0.3 \mathrm{mmol}), \quad$ bis(triphenylphosphine) palladium(II) dichloride $(16.0 \mathrm{mg}, 23.0 \mu \mathrm{mol})$, copper iodide $(4.4 \mathrm{mg}$, $23.0 \mu \mathrm{mol})$ were introduced in a dry shlenk under argon. Dry dimethylformamide $(16.0 \mathrm{~mL})$ was added, and the solution was degassed with argon bubbling for 10 minutes. Freshly distilled triethylamine $(0.42 \mathrm{~mL})$ was then added, and the solution degassed for another minute. The solution was stirred at room temperature for $24 \mathrm{hrs}$. TBABr $(0.5 \mathrm{~g}, 1.5 \mathrm{mmol})$ was added, and the product was precipitated by addition of excess diethylether. After centrifugation the solid was dissolved in minimum acetonitrile and precipitated by addition of excess ethanol. The resulting suspension was centrifugated and the solid washed with ethanol and diethylether to afford $0.52 \mathrm{~g}$ of a light-brown solid $(85 \%) . \delta_{\mathrm{H}}\left(300 \mathrm{MHz}, \mathrm{CD}_{3} \mathrm{CN}\right) 7.84$ $\left(\mathrm{d},{ }^{3} \mathrm{~J}=8.5 \mathrm{~Hz}, 2 \mathrm{H}, \mathrm{Ar}-H\right), 7.60\left(\mathrm{~d},{ }^{3} \mathrm{~J}=8.5 \mathrm{~Hz}, 2 \mathrm{H}, \mathrm{Ar}-H\right), 7.54\left(\mathrm{~d},{ }^{3} \mathrm{~J}=8.5 \mathrm{~Hz}, 2 \mathrm{H}\right.$, Ar- $H$ ), $7.40\left(\mathrm{~d},{ }^{3} \mathrm{~J}=8.5 \mathrm{~Hz}, 2 \mathrm{H}, \mathrm{Ar}-\mathrm{H}\right), 3.82\left(\mathrm{q},{ }^{3} \mathrm{~J}=8.5 \mathrm{~Hz}, 4 \mathrm{H}, \mathrm{N}-\mathrm{CH}_{2}-\mathrm{CH}_{3}\right), 3.14\left(\mathrm{~m}, 32 \mathrm{H}, \mathrm{N}-\mathrm{CH}_{2}-\right.$ $\left.\mathrm{CH}_{2}-\mathrm{CH}_{2}-\mathrm{CH}_{3}\right), 1.65\left(\mathrm{~m}, 32 \mathrm{H}, \mathrm{N}-\mathrm{CH}_{2}-\mathrm{CH}_{2}-\mathrm{CH}_{2}-\mathrm{CH}_{3}\right), 1.41\left(\mathrm{sex},{ }^{3} \mathrm{~J}=7.5 \mathrm{~Hz}, 32 \mathrm{H}, \mathrm{N}-\mathrm{CH}_{2}-\right.$ $\mathrm{CH}_{2}-\mathrm{CH}_{2}-\mathrm{CH}_{3}$ ), 1.28 (bs, 6H, N-CH$-\mathrm{CH}_{3}$ ), 1.00 (t, ${ }^{3} \mathrm{~J}=7.5 \mathrm{~Hz}, 48 \mathrm{H}, \mathrm{N}-\mathrm{CH}_{2}-\mathrm{CH}_{2}-\mathrm{CH}_{2}-\mathrm{CH}_{3}$ ); $\delta_{\mathrm{P}}\left(121 \mathrm{MHz}, \mathrm{CD}_{3} \mathrm{CN}\right)-13.34 ; \mathrm{m} / z$ (ESI-), most intense peaks (\%): $756.6(100)[\mathrm{M}]^{4-}$ requires 
756.5, $922.4(25)\left[\mathrm{PW}_{11} \mathrm{O}_{39} \mathrm{GeOH}+\mathrm{H}\right]^{3-}$ requires 922.0, 1009.1 (79) $[\mathrm{M}+\mathrm{H}]^{3-}$ requires 1009.0, $1089.5(40)[\mathrm{M}+\mathrm{TBA}]^{3-}$ requires $1089.5,1505.1(11)[\mathrm{M}-\mathrm{O}]^{2-}$ requires $1505.1,1634.8(20)$ $[\mathrm{M}+\mathrm{TBA}+\mathrm{H}]^{2-}$ requires $1634.3,1755.9(8)\left[\mathrm{M}+2 \mathrm{TBA}^{2-}\right.$ requires 1755.4; IR (KBr pellet, $\mathrm{cm}^{-}$ 1) $2962(\mathrm{~m}), 2936(\mathrm{~m}), 2874(\mathrm{~m}), 1483(\mathrm{~m}), 1382(\mathrm{w}), 1339(\mathrm{w}), 1240(\mathrm{w}), 1093(\mathrm{~m}), 1074$ (m), 964 (s), 887 (m), 809 (vs), 391 (m); elemental analysis for $\mathrm{C}_{82} \mathrm{H}_{162} \mathrm{GeN}_{7} \mathrm{O}_{39} \mathrm{PW}_{11}(\%)$ : calcd C 24.65, H 4.09, N 2.45; found C 24.50, H 3.96, N 2.54.

\subsection{Synthesis of $\mathrm{TBA}_{4}\left[\mathrm{PW}_{11} \mathrm{O}_{39}\left\{\mathrm{Ge}\left(\mathrm{C}_{6} \mathrm{H}_{4}\right) \mathrm{C} \equiv \mathrm{C}\left(\mathrm{C}_{6} \mathrm{H}_{4}\right) \mathbf{N H}_{2}\right\}\right] \mathbf{K}_{\mathrm{Ge}}\left[\mathrm{NH}_{2}\right] . \mathrm{K}_{\mathrm{Ge}}[\mathrm{I}](0.2 \mathrm{~g}$,} $51.0 \mu \mathrm{mol})$, 4-ethynylaniline $(12.0 \mathrm{mg}, 0.10 \mathrm{mmol})$, bis-(triphenylphosphine) palladium(II) dichloride $(5.4 \mathrm{mg}, 7.64 \mu \mathrm{mol})$, copper iodide $(1.4 \mathrm{mg}, 7.64 \mu \mathrm{mol})$ were introduced in a dry shlenk under argon. Dry dimethylformamide $(5.0 \mathrm{~mL})$ was added, and the solution was degassed with argon bubbling for 10 minutes. Freshly distilled triethylamine $(0.14 \mathrm{~mL})$ was then added, and the solution degassed for another minute. The solution was stirred at room temperature for $24 \mathrm{hrs}$. TBABr $(0.2 \mathrm{~g}, 0.6 \mathrm{mmol})$ was added and the product was precipitated by addition of excess diethylether. After centrifugation the solid was dissolved in minimum acetonitrile and precipitated by addition of excess ethanol. The resulting suspension was centrifugated and the solid washed with ethanol and diethylether to afford $0.19 \mathrm{~g}$ of a lightbrown solid $(95 \%) . \delta_{\mathrm{H}}\left(300 \mathrm{MHz}, \mathrm{CD}_{3} \mathrm{CN}\right) 7.81\left(\mathrm{~d},{ }^{3} \mathrm{~J}=8.5 \mathrm{~Hz}, 2 \mathrm{H}, \mathrm{Ar}-H\right), 7.54\left(\mathrm{~d},{ }^{3} \mathrm{~J}=\right.$ $8.5 \mathrm{~Hz}, 2 \mathrm{H}, \operatorname{Ar}-H), 7.31\left(\mathrm{~d},{ }^{3} \mathrm{~J}=8.5 \mathrm{~Hz}, 2 \mathrm{H}, \operatorname{Ar}-H\right), 6.67\left(\mathrm{~d},{ }^{3} \mathrm{~J}=8.5 \mathrm{~Hz}, 2 \mathrm{H}, \operatorname{Ar}-H\right), 4.47$ (s, $\left.2 \mathrm{H}, \mathrm{N} H_{2}\right), 3.14\left(\mathrm{~m}, 32 \mathrm{H}, \mathrm{N}-\mathrm{CH}_{2}-\mathrm{CH}_{2}-\mathrm{CH}_{2}-\mathrm{CH}_{3}\right), 1.65$ (m, 32H, N-CH $\left.-\mathrm{CH}_{2}-\mathrm{CH}_{2}-\mathrm{CH}_{3}\right), 1.41$ ( $\left.\mathrm{sex},{ }^{3} \mathrm{~J}=7.5 \mathrm{~Hz}, 32 \mathrm{H}, \mathrm{N}-\mathrm{CH}_{2}-\mathrm{CH}_{2}-\mathrm{CH}_{2}-\mathrm{CH}_{3}\right), 1.00$ (t, ${ }^{3} \mathrm{~J}=7.5 \mathrm{~Hz}, 48 \mathrm{H}, \mathrm{N}-\mathrm{CH}_{2}-\mathrm{CH}_{2}-\mathrm{CH}_{2}-$ $\left.\mathrm{CH}_{3}\right) ; \delta_{\mathrm{P}}\left(121 \mathrm{MHz}, \mathrm{CD}_{3} \mathrm{CN}\right)-13.35 ; \mathrm{m} / \mathrm{z}$ (ESI-), most intense peaks (\%): 735.3 (34) [M] $]^{4-}$ requires 735.5, $980.7(100)[\mathrm{M}+\mathrm{H}]^{3-}$ requires 981.0, $1462.6(58)[\mathrm{M}-\mathrm{O}]^{2-}$ requires 1463.0, $1592.2(21)[\mathrm{M}+\mathrm{TBA}+\mathrm{H}]^{2-}$ requires 1592.2; IR (KBr pellet, $\left.\mathrm{cm}^{-1}\right) 3365(\mathrm{w}), 2962(\mathrm{~m}), 2934$ (m), $2874(\mathrm{w}), 2206(\mathrm{w}), 1623(\mathrm{w}), 1607$ (w), $1590(\mathrm{w}), 1518(\mathrm{w}), 1483(\mathrm{~m}), 1380(\mathrm{w}), 1094$ (m), 1073 (m), 964 (s), 887 (m), 807 (vs), 390 (m); elemental analysis for $\mathrm{C}_{78} \mathrm{H}_{154} \mathrm{GeN}_{5} \mathrm{O}_{39} \mathrm{PW}_{11}$ (\%): calcd C 23.95, H 3.97, N 1.79; found C 24.34, H 3.93, N 1.95.

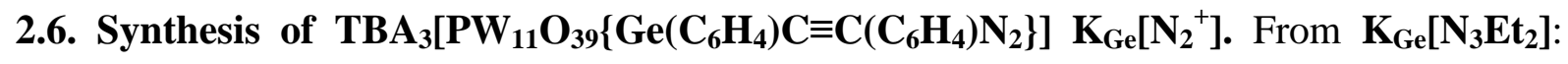

$\mathbf{K}_{\mathbf{G e}}\left[\mathbf{N}_{\mathbf{3}} \mathbf{E t}_{2}\right](40.0 \mathrm{mg}, 10.0 \mu \mathrm{mol})$, was dissolved in acetonitrile $(2.0 \mathrm{~mL})$. Hydrochloric acid $0.1 \mathrm{M}$ in acetonitrile $(0.5 \mathrm{~mL}, 0.05 \mathrm{mmol})$ was added and the solution was stirred for five minutes. TBAPF $_{6}(80.0 \mathrm{mg}, 0.2 \mathrm{mmol})$ was added and the product was precipitated with excess diethylether to afford $120 \mathrm{mg}$ of a light yellow powder (99\%, excess mass is due to

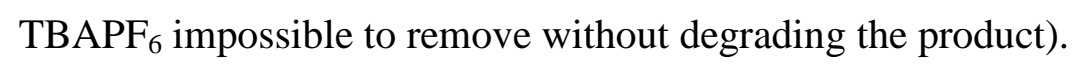


From $\mathbf{K}_{\mathbf{G e}}\left[\mathbf{N H}_{\mathbf{2}}\right]$ : $\mathbf{K}_{\mathbf{G e}}\left[\mathbf{N H}_{2}\right](60.0 \mathrm{mg}, 15.3 \mu \mathrm{mol})$, was dissolved in dimethylformamide (3.0 $\mathrm{mL})$. Nitrosonium tetrafluoroborate $(16.1 \mathrm{mg}, 0.14 \mathrm{mmol})$ was added and the solution was stirred for 15 minutes. $\mathrm{TBABr}(80.0 \mathrm{mg}, 0.2 \mathrm{mmol})$ was added and the product was precipitated with excess ethanol. The resulting suspension was centrifugated and the solid washed with ethanol and diethylether to afford $40.0 \mathrm{mg}$ of a yellow powder $(67 \%)$.

$\delta_{\mathrm{H}}\left(300 \mathrm{MHz}, \mathrm{CD}_{3} \mathrm{CN}\right) 8.62\left(\mathrm{~d},{ }^{3} \mathrm{~J}=8.5 \mathrm{~Hz}, 2 \mathrm{H}, \mathrm{Ar}-H\right), 7.83\left(\mathrm{~d},{ }^{3} \mathrm{~J}=8.5 \mathrm{~Hz}, 2 \mathrm{H}, \mathrm{Ar}-H\right), 7.79$ $\left(\mathrm{d},{ }^{3} \mathrm{~J}=8.5 \mathrm{~Hz}, 2 \mathrm{H}, \mathrm{Ar}-H\right), 7.69\left(\mathrm{~d},{ }^{3} \mathrm{~J}=8.5 \mathrm{~Hz}, 2 \mathrm{H}, \mathrm{Ar}-\mathrm{H}\right), 3.14\left(\mathrm{~m}, 32 \mathrm{H}, \mathrm{N}-\mathrm{CH}_{2}-\mathrm{CH}_{2}-\mathrm{CH}_{2}-\right.$ $\mathrm{CH}_{3}$ ), $1.65\left(\mathrm{~m}, 32 \mathrm{H}, \mathrm{N}-\mathrm{CH}_{2}-\mathrm{CH}_{2}-\mathrm{CH}_{2}-\mathrm{CH}_{3}\right), 1.41$ (sex, ${ }^{3} \mathrm{~J}=7.5 \mathrm{~Hz}, 32 \mathrm{H}, \mathrm{N}-\mathrm{CH}_{2}-\mathrm{CH}_{2}-\mathrm{CH}_{2}-$ $\left.\mathrm{CH}_{3}\right), 1.00\left(\mathrm{t},{ }^{3} \mathrm{~J}=7.5 \mathrm{~Hz}, 48 \mathrm{H}, \mathrm{N}-\mathrm{CH}_{2}-\mathrm{CH}_{2}-\mathrm{CH}_{2}-\mathrm{CH}_{3}\right)$; IR (KBr pellet, $\left.\mathrm{cm}^{-1}\right) 2962(\mathrm{~m}), 2934$ (m), 2874 (w), 2256 (w), 2208 (w), 1573 (m), 1483 (m), 1381 (w), 1093 (m), 1074 (s), 965 (s), 887 (s), 806 (vs), 390 (s).

2.7. Surface grafting. The three-electrode electrochemical cell was filled with a $1 \mathrm{mM}$ solution of $\mathbf{K}_{\mathbf{G e}}\left[\mathbf{N}_{2}^{+}\right]$in acetonitrile with $0.1 \mathrm{M} \mathrm{TBAPF}_{6}$. Grafting was carried out by cyclic voltammetry $(\mathrm{CV})$ with 6 cycles between -0.2 and $-0.8 \mathrm{~V} / \mathrm{SCE}$ at a scan rate, $\mathrm{v}=100 \mathrm{mV} . \mathrm{s}^{-1}$. Modified electrodes were rinsed by ultrasonication in acetonitrile and DMF ( 5 min each) and dried with an argon flow.

2.8. Electrochemical studies. A freshly polished or modified glassy carbon electrode was used as the working electrode. The cell was filled with a blank $0.1 \mathrm{M} \mathrm{TBAPF}_{6}$ solution in acetonitrile for characterization of the glassy carbon electrode either i) in the presence of $\mathbf{K}_{\mathbf{G e}}[\mathbf{I}]$ or ii) grafted with $\mathrm{K}_{\mathrm{Ge}}$ from $\mathbf{K}_{\mathbf{G e}}\left[\mathbf{N}_{\mathbf{2}}{ }^{+}\right]$. CVs between 0 and $-1.8 \mathrm{~V} / \mathrm{SCE}$ were obtained at different scan rates (from $\mathrm{v}=0.1$ to $500 \mathrm{~V} \cdot \mathrm{s}^{-1}$ ) and compensating at each $\mathrm{v}$ for the solution resistance.

\section{RESULTS AND DISCUSSION}

3.1. Synthesis. The synthesis of a new organic inorganic hybrid platform based on a Keggin-type POM was the first step toward the formation of the diazonium target. Starting from the monolacunary Keggin-type compound $\mathrm{K}_{7}\left[\mathrm{PW}_{11} \mathrm{O}_{39}\right] \cdot 14 \mathrm{H}_{2} \mathrm{O}$, reaction with trichloro(4-iodophenyl)germane in a 1:1 water/DMF mixture gave the iodoaryl-terminated plateform $\left[\mathrm{PW}_{11} \mathrm{O}_{39}\left\{\mathrm{Ge}\left(p-\mathrm{C}_{6} \mathrm{H}_{4} \mathrm{I}\right)\right\}\right]^{4-} \mathbf{K}_{\mathbf{G e}}[\mathbf{I}]$. Addition of tetrabutylammonium bromide (TBABr) induced precipitation of the hybrid as a TBA salt. This germanium-based platform has very similar properties (chemical structure, redox behaviour and reactivity) to the organo- 
tin analogue and thus provides an alternative to the use of toxic alkyl tin compounds. ${ }^{33}$ Furthermore, the use of germanium instead of tin allows a more straightforward synthesis of the hybrid. Indeed, trichloro(4-iodophenyl)germane can be synthesized in a one pot reaction from commercially available tetrachlorogermane and diiodobenzene. Moreover, $\mathrm{pH}$ control is no longer necessary in the case of germanium as the synthesis proceeds in a mixed organicaqueous solution. The presence of the iodoaryl moiety in $\mathbf{K}_{\mathbf{G e}}[\mathbf{I}]$ should allow access to a wide range of compounds through palladium-catalysed cross-coupling reactions. ${ }^{8}$ Two routes toward the diazonium target were pursued (Scheme 1).

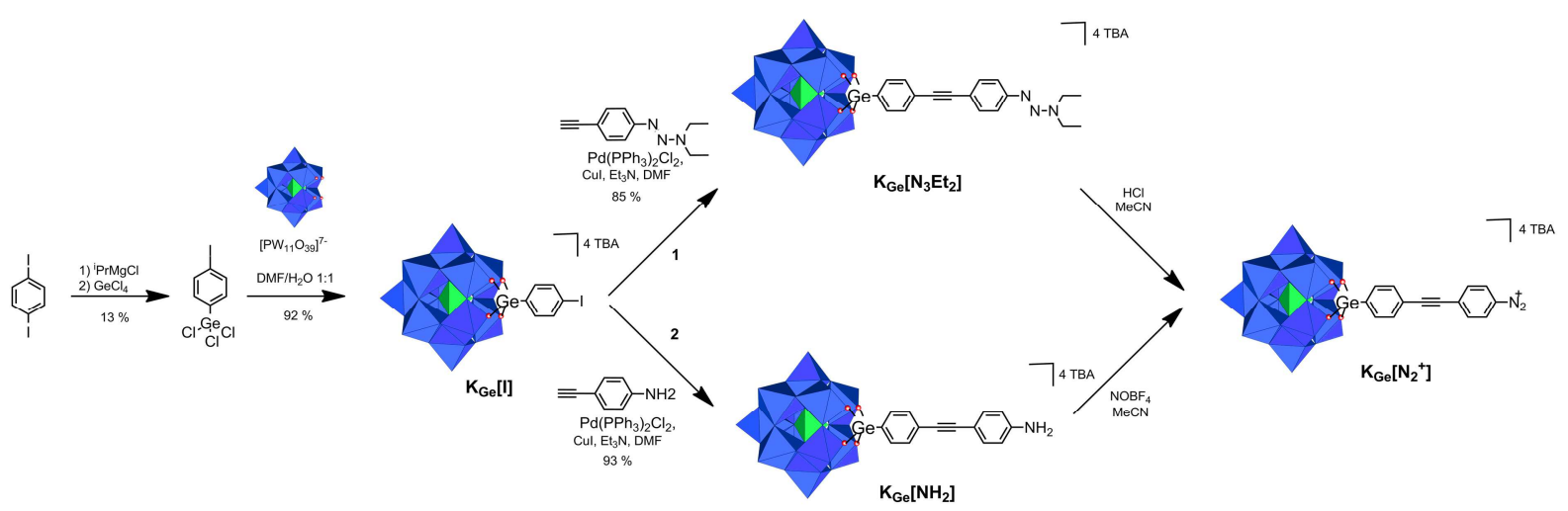

Scheme 1. Synthetic routes to the diazonium-terminated hybrid $\mathbf{K}_{\mathbf{G e}}\left[\mathbf{N}_{\mathbf{2}}{ }^{+}\right]$

The first route (Scheme 1), with a triazene function as the diazonium precursor, is adapted from the functionalization of a Lindqvist-type POM. ${ }^{34}$ Sonogashira coupling of the iodideterminated platform $\mathbf{K}_{\mathbf{G e}}[\mathbf{I}]$ with 4-ethynylphenyltriazene gave the coupling product $\mathbf{K}_{\mathbf{G e}}\left[\mathbf{N}_{\mathbf{3}} \mathbf{E} \mathbf{t}_{2}\right]$ quantitatively. The diazonium-terminated hybrid $\mathbf{K}_{\mathbf{G e}}\left[\mathbf{N}_{\mathbf{2}}{ }^{+}\right]$was formed by subsequent addition of hydrochloric acid to $\mathbf{K}_{\mathbf{G e}}\left[\mathbf{N}_{\mathbf{3}} \mathbf{E} \mathbf{t}_{2}\right]$ in acetonitrile. This reaction was monitored by ${ }^{1} \mathrm{H}$ NMR spectroscopy (Figure 1). Upon addition of hydrochloric acid, a unique set of 4 aromatic doublets arises. These new doublets are more deshielded than those of $\mathbf{K}_{\mathbf{G e}}\left[\mathbf{N}_{\mathbf{3}} \mathbf{E} \mathbf{t}_{2}\right]$, in agreement with the formation of a diazonium function. ${ }^{34}$ Three equivalents of acid are required for the reaction to go to completion. As a consequence, the TBA cations are partially exchanged by protons, leading to the product as a mixed TBA and proton salt showing modified redox behaviours (not shown, discussed below). The diazonium-terminated

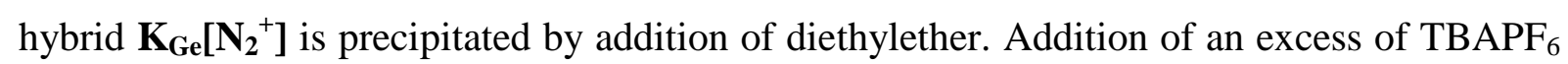
before precipitation allows significant exchange of the proton counterions, leading to the TBA salt as the major product. $\mathbf{K}_{\mathbf{G e}}\left[\mathbf{N}_{2}^{+}\right]$is stable in its solid form, however in solution it degrades within a few hours, making it hard to purify and further characterize. Its infrared spectrum shows a new band at $2256 \mathrm{~cm}^{-1}$ assigned to the $\mathrm{N} \equiv \mathrm{N}$ stretch of the diazonium group. 
In a second route (Scheme 1), the diazonium hybrid $\mathbf{K}_{\mathbf{G e}}\left[\mathbf{N}_{\mathbf{2}}{ }^{+}\right]$is formed from reaction between the related amine and nitrosonium tetrafluoroborate. Palladium-catalysed Sonogashira coupling of the $\mathbf{K}_{\mathbf{G e}}[\mathbf{I}]$ platform with 4-ethynylaniline gave the amine-terminated hybrid $\mathbf{K}_{\mathbf{G e}}\left[\mathbf{N H}_{2}\right]$ quantitatively, which per se enlarges our family of hybrid POM platforms ready for post-functionalization and incorporation into various POM-based molecular materials. As for the triazene route, the reaction between $\mathbf{K}_{\mathbf{G e}}\left[\mathbf{N H}_{2}\right]$ and nitrosonium tetrafluoroborate in acetonitrile was monitored by ${ }^{1} \mathrm{H}$ NMR spectroscopy. Six equivalents of nitrosonium are necessary for the reaction to go to completion. ${ }^{1} \mathrm{H}$ NMR and IR spectroscopies of the diazonium synthesized by both methods are similar. ${ }^{1} \mathrm{H}$ NMR shifts of the aromatic signals slightly vary according to the concentration, but are always shifted downfield compared to the precursor ones. When used in an electrografting context, diazonium compounds are often prepared in situ because of their poor stability. ${ }^{35}$ However, the electrochemical features of the in situ prepared $\mathbf{K}_{\mathbf{G e}}\left[\mathbf{N}_{2}{ }^{+}\right]$are ill-defined. This is attributed to the presence of protons that, in a large extent, affect the redox properties of the POM, by shifting the electrochemical waves to higher potentials. ${ }^{10,36}$ As a consequence, grafting from the isolated diazonium-terminated product was preferred.

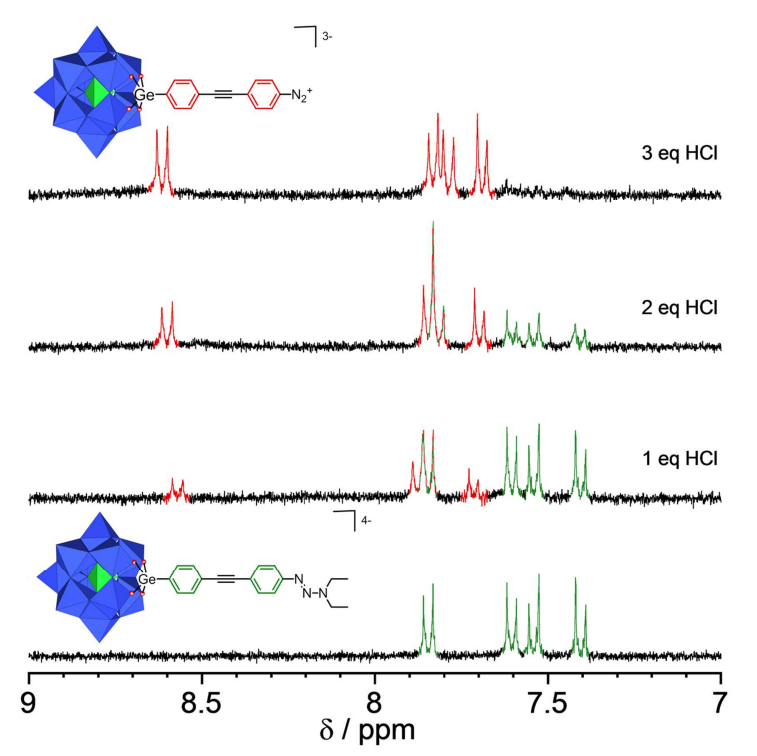

Figure 1. ${ }^{1} \mathrm{H}$ NMR monitoring of the formation of the diazonium-derived hybrid $\mathrm{K}_{\mathrm{Ge}}\left[\mathrm{N}_{2}^{+}\right]$from $\mathrm{K}_{\mathrm{Ge}}\left[\mathrm{N}_{3} \mathrm{Et}_{2}\right]$

3.2. Electrochemical grafting. Grafting of the isolated diazonium-terminated hybrid $\mathbf{K}_{\mathbf{G e}}\left[\mathbf{N}_{\mathbf{2}}^{+}\right]$on glassy carbon (GC) electrodes was achieved through electrochemical reduction of the diazonium function. Monoelectronic reduction of aryl diazonium salts generally leads to a dediazonation step producing a reactive aryl radical. When reduction is performed electrochemically, the aryl radical, formed in the vicinity of the surface, immediately reacts 
with a surface site, leading to a covalent bond. The electrochemical characterization of $\mathbf{K}_{\mathbf{G e}}\left[\mathbf{N}_{\mathbf{2}}{ }^{+}\right]$in acetonitrile shows an irreversible wave around $-0.5 \mathrm{~V} / \mathrm{SCE}$ attributed to the reduction of the diazonium function and two quasi-reversible waves around -1.0 and -1.5 V/SCE corresponding to the first and second monoelectronic reductions of the POM. A general electrochemical method for grafting compounds bearing a diazonium function is to perform several electrochemical cycles around the diazonium reduction potential. Six cycles between -0.2 and $-0.8 \mathrm{~V} / \mathrm{SCE}$, were fulfilled (Figure SI-8). The diazonium wave decreased upon cycling, attesting the grafting of the POMs, the surface being less and less accessible to species in solution as it is being covered by the grafted molecules.

\subsection{Electrochemical characterization and kinetic studies}

Voltammetry of $\mathbf{K}_{\mathrm{Ge}}[\mathbf{I}]$ in solution. $\mathbf{K}_{\mathbf{G e}}[\mathbf{I}]$ was taken as a reference compound to describe the electrochemical behavior of the POM in solution. The cyclic voltammetry of $\mathbf{K}_{\mathbf{G e}}[\mathbf{I}]$ in a $0.1 \mathrm{M} \mathrm{TBAPF}_{6}$ acetonitrile solution is characterized by two successive reversible reduction waves (Figure 2a). Their respective reversible potentials $E^{0}=\left(E_{p, r e d}+E_{p, o x}\right) / 2$ are -0.99 and $1.46 \mathrm{~V} / \mathrm{SCE}$. At low scan rates $\left(\mathrm{v}=0.1\right.$ to $\left.1 \mathrm{~V} \cdot \mathrm{s}^{-1}\right)$ and with appropriate compensation of the electrolyte solution resistance, the peak-to-peak separation, $\Delta \mathrm{E}_{\mathrm{p}}=\mathrm{E}_{\mathrm{p}, \mathrm{ox}}-\mathrm{E}_{\mathrm{p} \text {,red }}$, is $65(+/-5 \mathrm{mV})$ for both systems. Since $\Delta \mathrm{E}_{\mathrm{p}}$ is close to the predicted value of $59 \mathrm{mV}$, both processes correspond to a reversible one-electron transfer at this timescale. The peak current, $\mathrm{i}_{\mathrm{p}, \mathrm{red}}$, associated to the first reduction process is proportional to the square root of the scan rate in agreement with a diffusion-limited process (not shown). A diffusion coefficient $D_{\mathrm{sol}}=0.93 \times 10^{-5} \mathrm{~cm}^{2} \cdot \mathrm{s}^{-1}$ for $\mathbf{K}_{\mathbf{G e}}[\mathbf{I}]$ can be deduced from the peak current intensity, $\mathrm{i}_{\mathrm{p}, \text { red }}$ in agreement with values reported for other POM structures. ${ }^{37}$
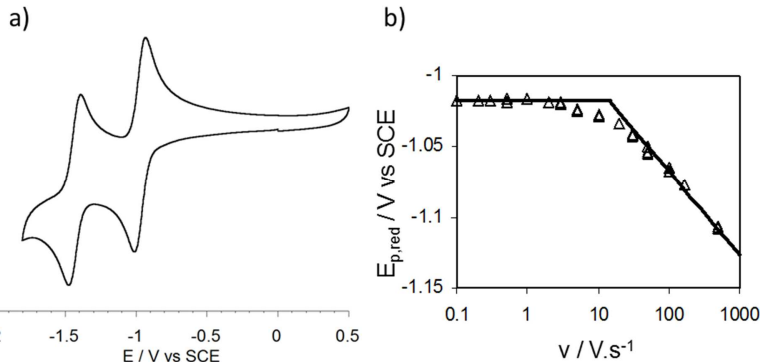

Figure 2. a) Cyclic voltammetry at a glassy carbon electrode ( $2 \mathrm{~mm}$ diameter) of $\mathbf{K}_{\mathrm{Ge}}[\mathbf{I}](1 \mathrm{mM})$ in a $0.1 \mathrm{M}$ $\mathrm{TBAPF}_{6} \mathrm{MeCN}$ solution at the scan rate $\mathrm{v}=0.1 \mathrm{~V} \cdot \mathrm{s}^{-1}$; b) $1^{\text {st }}$ reduction peak potential variation with v. Symbols: experimental values, lines: predicted variations, see text. 
Kinetics studies in solution. A key parameter for the use of POMs as components of fast communicating molecular electronic devices for information storage is the writing/reading response time. A first insight into the kinetics of charge transfer processes to the POM can be obtained from the variation of the voltammetric features $\left(\Delta \mathrm{E}_{\mathrm{p}}\right.$ or equivalently $\left.\mathrm{E}_{\mathrm{p}, \mathrm{red}}\right)$ with the potential scan rate (Figure $2 \mathrm{~b}$ ). For $\mathrm{v}<3 \mathrm{~V} \cdot \mathrm{s}^{-1}, \Delta \mathrm{E}_{\mathrm{p}}$ is constant, in agreement with a fast and reversible charge injection. For higher scan rates, the peak-to-peak separation increases and for $\mathrm{v}>30 \mathrm{~V} \cdot \mathrm{s}^{-1}, \mathrm{E}_{\mathrm{p} \text {,red }}$ decreases by $60 \mathrm{mV}$ per decade of $\mathrm{v}$ in agreement with a limitation by the slow kinetics of the quasi-reversible electron transfer (ET) process. Under such kinetic limitation $\mathrm{E}_{\mathrm{p}, \text { red }}$ is given by: ${ }^{38}$

$\mathrm{E}_{\mathrm{p}, \mathrm{red}}=\mathrm{E}^{0}-\mathrm{RT} / \alpha \mathrm{F}\left[0.78-\ln \left(\mathrm{k}_{\mathrm{ET}, \mathrm{sol}}\left(\mathrm{RT} / \alpha \mathrm{D}_{\mathrm{sol}} \mathrm{Fv}\right)^{1 / 2}\right)\right]$

with $\alpha$ the electron transfer coefficient $(\alpha=0.5), \mathrm{k}_{\mathrm{ET}, \text { sol }}$ the ET rate constant for the dissolved species and $\mathrm{D}_{\mathrm{sol}}$ its diffusion coefficient. Knowing $\mathrm{E}^{0}$ and $\mathrm{D}_{\mathrm{sol}}, \mathrm{k}_{\mathrm{ET} \text {,sol }}=0.064 \mathrm{~cm} \cdot \mathrm{s}^{-1}$ ensues from the $E_{p, r e d}$ variations. The kinetic of the second electron transfer is more difficult to evaluate at high scan rates as it is close to the first one; however, the asymptotic decrease of $\mathrm{E}_{\mathrm{p}, \mathrm{red}}$ by $60 \mathrm{mV}$ per decade of $\mathrm{v}$ occurs at similar scan rates for both reduction processes, indicating that both injections of electrons in the dissolved POM are performed at similar rates $\left(\mathbf{K}_{\mathbf{G e}}[\mathbf{I}]-\mathbf{1 e}\right.$ and $\left.\mathbf{K}_{\mathbf{G e}}[\mathbf{I}]-\mathbf{2} \mathbf{e}\right)$.

Voltammetry of $\mathbf{K}_{\mathbf{G e}}$ immobilized at a GC surface. The voltammetry of the GC electrode grafted with the POM by reduction of the corresponding diazonium group of $\mathbf{K}_{\mathbf{G e}}\left[\mathbf{N}_{\mathbf{2}}{ }^{+}\right]$was inspected. Once grafted, the modified electrodes were thoroughly sonicated in acetonitrile and dimethylformamide, and a CV (Figure 3a,b) was recorded in a $0.1 \mathrm{M} \mathrm{TBAPF}_{6}$ solution in acetonitrile. As no electrochemically active species is present in solution, redox signals arise from surface immobilized products. Two reversible reduction waves at $\mathrm{E}^{0}=-1.01$ and -1.50 V/SCE are present, corresponding to the first and second one-electron reductions of the POM framework. The reduction potentials of the immobilized POM are similar to those in solution. For immobilized species, $\Delta \mathrm{E}_{\mathrm{p}}=0$ is expected for a reversible one-electron process, it is $c a$. $30 \mathrm{mV}$ and $60 \mathrm{mV}$ respectively for the first and second processus in immobilized POMs. However, at low scan rates, the peak-to-peak separation, $\Delta \mathrm{E}_{\mathrm{p}}$, or the reduction peak potential, $\mathrm{E}_{\mathrm{p}, \mathrm{red}}$, are unchanged when increasing the scan rate, in agreement with a fast electron transfer process. The non-ideal values of $\Delta \mathrm{E}_{\mathrm{p}}$ are then not related to kinetic limitations. These deviations from ideality have already been observed for different immobilized systems. ${ }^{39-42}$ Such manifestation of hysteretic behaviour is indicative of non-equilibrium phenomena 
arising from slow dissipative structural changes at the time scale of the experiment, associated to the redox process. ${ }^{39}$ In the case of redox transformations of highly charged systems, ${ }^{43}$ such as immobilized POMs, and more particularly in conducting polymers, ${ }^{44}$ it is also indicative of limitation from the ion intercalation process, Such interpretation is comforted by the increase of the $\Delta \mathrm{E}_{\mathrm{p}}$ value with the number of injected electrons ( $2^{\text {nd }} \mathrm{ET}$ vs $1^{\text {st }} \mathrm{ET}$ ).

The wave current was integrated to estimate the layer grafting density. The amount of charge transferred in a single step is about $0.25 \mu \mathrm{C}$, giving a POM grafting density: $\Gamma=\mathrm{Q} / \mathrm{FA}=$ $8.2 \times 10^{-11} \mathrm{~mol} . \mathrm{cm}^{-2}$. With respect to the design of POM-based molecular memory devices, this corresponds to the possible injection of $8 \mu \mathrm{C} / \mathrm{cm}^{2}$, a value which compares well with the capacity of the classical devices using $\mathrm{Si} / \mathrm{SiO}_{2}$ technology. Based on the crystal structure of the reduced $\mathrm{TBA}_{4}\left[\mathrm{PW}_{12} \mathrm{O}_{40}\right]$, the distance between two POMs is $1.44 \mathrm{~nm} .{ }^{45}$ Assuming that a POM occupies $1.8 \mathrm{~nm}^{2},{ }^{46}$ a closely packed POM layer would have a density of $\Gamma=9.2 \times 10^{-11}$ mol.cm ${ }^{-2}$. The grafting density deduced from electrochemical measurements, although slightly approximate, is in agreement with the formation of a compact monolayer. ${ }^{29}$ It should be noted that these films are indeed very compact: for example with simple organic groups such as nitrophenyl the highest experimental value reached is only $21 \pm 3 \%$ of the theoretical maximum surface concentration for a close packed monolayer. ${ }^{47}$
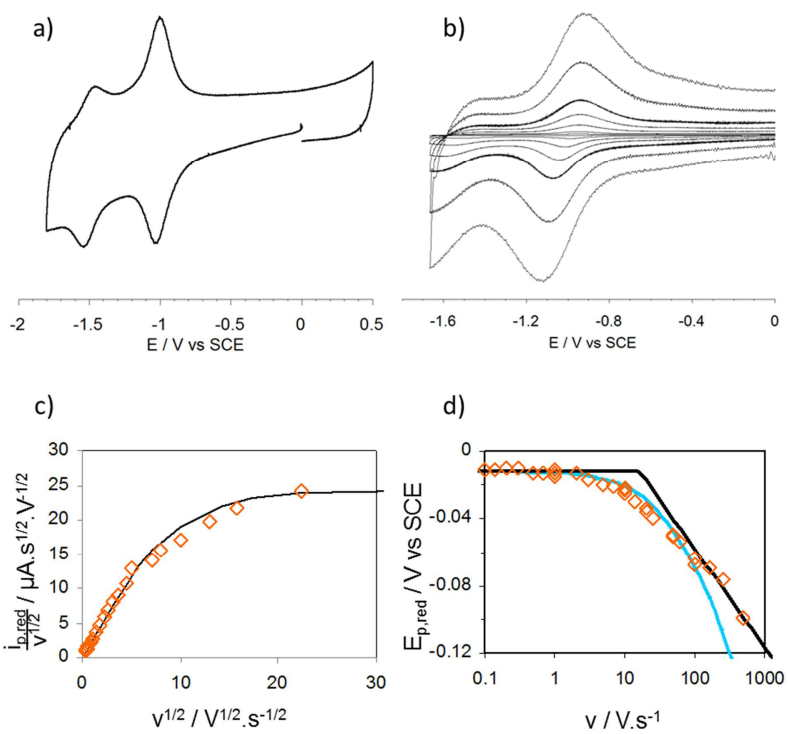

Figure 3. a-d) Cyclic voltammetry of the $\mathbf{K}_{\mathbf{G e}}$-grafted glassy carbon electrode ( $2 \mathrm{~mm}$ diameter) in a $0.1 \mathrm{M}$ $\mathrm{TBAPF}_{6} \mathrm{MeCN}$ solution; a) scan rate, $\left.\mathrm{v}=0.1 \mathrm{~V} \cdot \mathrm{s}^{-1} ; \mathrm{b}\right) \mathrm{v}=1,5,20,50,100,250$ and $500 \mathrm{~V} \cdot \mathrm{s}^{-1} ; 1^{\text {st }}$ peak c) current and d) potential variation with v. Symbols: experimental values, lines: predicted variations, see text.

An independent estimate of the grafting density was obtained by Rutherford Back Scattering (RBS, details in SI) analysis on a $1 \mathrm{~cm}^{2}$ grafted GC electrode, using the same procedure as for 
the grafting on the glassy carbon millimetre electrodes. The recorded signal allows to estimate the density of immobilized tungsten atoms at $8.3 \times 10^{14} \pm 0.3 \mathrm{~W} \cdot \mathrm{cm}^{-2}$ and thus a POM grafting density of $1.25 \times 10^{-10} \mathrm{~mol} . \mathrm{cm}^{-2}$. The calculations of the grafting density do not take into account the specific area of the macroscopic GC electrode, which may explain that the density estimated by RBS is $45 \%$ higher than by integration of the charge. However, both values obtained by RBS and electrochemistry suggest that the electrografting procedure leads to the formation of a monolayer.

Grafting of aryl diazonium salts often leads to multilayer formation. ${ }^{18}$ Indeed, aryl radicals can readily react with already grafted aryls leading to multilayer structures. However, the use of bulky groups atop the aryl group prevents the attack of a second radical, allowing for the controlled formation of monolayers. ${ }^{29}$ Here, the presence of the bulky POM on top of the aryl group probably has a similar effect.

Kinetics studies for the immobilized POM. Again, estimate of the ET kinetic performances of POM-anchored surfaces is essential to assess their potentialities in molecular memories. As for dissolved species, such information is obtained from the variation of the features of the $\mathrm{CVs}$ of the modified electrode with the potential scan rate, as displayed in Figure $3 \mathrm{~b}-\mathrm{d}$ for $\mathrm{v}$ ranging from 0.1 to $500 \mathrm{~V} . \mathrm{s}^{-1}$. First, the cathodic peak current intensity, $\mathrm{i}_{\mathrm{p}, \text { red }}$, evolution with $\mathrm{V}$ is displayed in the form of $\mathrm{i}_{\mathrm{p}, \text { red }} / \mathrm{v}^{1 / 2}$ variation with $\mathrm{v}^{1 / 2}$ in Figure $3 \mathrm{c}$. For $\mathrm{v}<30 \mathrm{~V} \cdot \mathrm{s}^{-1}$, a linear dependence of $i_{p \text {,red }}$ with $v$ is observed in agreement with a surface confined redox process (see left part of Fig 3c). The grafting layer density obtained from such linear variation, ${ }^{38} \Gamma=$ $4 \mathrm{i}_{\mathrm{p}, \text { red }} \mathrm{RT} / \mathrm{AF}^{2} \mathrm{v}=8.3 \times 10^{-11} \mathrm{~mol} . \mathrm{cm}^{-2}$, agrees with that obtained from direct integration of the voltammograms. At higher rates, $v>50 \mathrm{~V} \cdot \mathrm{s}^{-1}, \mathrm{i}_{\mathrm{p}, \text { red }}$ tends toward a linear variation with the square root of the scan rate, indicating the occurrence of a diffusion-limited process (see right part of Fig 3c).

The variation of the peak potential, $\mathrm{E}_{\mathrm{p}, \mathrm{red}}$, with the scan rate is displayed in Figure $3 \mathrm{~d}$. For $\mathrm{v}<$ $10 \mathrm{~V} . \mathrm{s}^{-1}$, the ET to the immobilized species is fast as $\mathrm{E}_{\mathrm{p}, \mathrm{red}}$ is unchanged with v. For higher values of $v, E_{p, r e d}$ decreases with $v$ indicating kinetic limitations by the heterogeneous ET. The ET rate constant can be obtained from comparison of $E_{p, r e d}$ with theoretical values according to Laviron's procedure. ${ }^{48}$ The theoretical variations of $E_{p, r e d}$ with $v$ are presented as the blue curve in Figure 3d: the fit is obtained for an ET rate constant to the immobilised POM $\mathrm{k}_{\mathrm{ET}, \mathrm{imm}}$ equal to $800 \mathrm{~s}^{-1}$. At first sight, the agreement with the experimental values of $E_{p, r e d}$ is good (for $\mathrm{v}<100 \mathrm{~V} . \mathrm{s}^{-1}$ ) and indicates that $800 \mathrm{~s}^{-1}$ corresponds to a characteristic rate of the kinetic limitation at play in the charge transfer process to the immobilized POM. A more careful 
inspection of the $E_{p, r e d}$ variations shows that at $v>50 \mathrm{~V} . \mathrm{s}^{-1}$, the predicted $\mathrm{E}_{\mathrm{p}, \text { red }}$ are more negative than the experimentally observed ones. Indeed, under pure kinetic control by the ET at surface confined systems, $E_{p, r e d}$ is predicted to decrease by $120 \mathrm{mV}$ per decade of $\mathrm{v}$. Actually, $E_{p, r e d}$ rather decreases by $60 \mathrm{mV}$ per decade of $\mathrm{v}$, as expected for a kinetic limitation by a diffusion process which confirms the observations and conclusions made on the $\mathrm{i}_{\mathrm{p} \text {,red }}$ variations in the same range of scan rates.

Diffusion-limitation, typically observed in redox immobilized architectures, ${ }^{49}$ is generally attributed to electron hopping between adjacent fixed redox centers accompanied by a movement of electroinactive counter ions that maintain the electroneutrality. Formally, this propagation of electron (associated to a counter-ion transport) in a thin layer was shown to be equivalent to the diffusion of the immobile redox center. ${ }^{50-52}$ Hopping is then depicted by an apparent diffusion coefficient, $\mathrm{D}_{\mathrm{ap}}$, which characterizes the electron transfer rate constant between the immobile redox centers. For highly charged systems, $D_{a p}$, may also contain the contribution of the physical diffusion of counter-ions during their relocating between redox sites upon electron hopping. ${ }^{53,54}$ Electron hopping is classically observed in multilayered systems, such as redox polymers deposited on electrodes. ${ }^{49}$ It has also been observed, to a lesser extent, in monolayer systems. ${ }^{55-57}$ Different hopping situations have been encountered. It is responsible for fast lateral communication between adjacent redox centers in functionnalized dendrimers, ${ }^{55}$ mesoscopic films of oxide nanoparticles, ${ }^{58}$ or at functionnalized insulating substrates. ${ }^{57}$ At monolayer-bound electrodes, electron hopping also explains ET through long distances, $>1 \mathrm{~nm}$, from the electrode, such as for redox centers anchored by long tethering chains or assemblies of NPs. ${ }^{59,60}$ A dense monolayer of POM has a characteristic thickness of $c a .2 .1 \mathrm{~nm}$ with inter-POM distance of about $1.5 \mathrm{~nm}$ which compares well with the monoelectronic injection of electrons in layers of $2 \mathrm{~nm}$ diameter NPs, 59,60 and supports possible hopping limitation.

The impact of the electrode scan rate on both $i_{p, r e d}$ and $E_{p, r e d}$ for the reduction of a confined electroactive species with intervention of diffusion (hopping or true diffusion of electroinactive ions) has been described theoretically. ${ }^{50,51,61,62}$ Analytical expressions of $i_{p, \text { red }}$ and $\mathrm{E}_{\mathrm{p} \text {,red }}$ with the scan rate have been proposed by Aoki et al. and confronted here to depict the experimental variations (see curve in Figure 3d). Diffusion characteristics can also be obtained from the electrochemical behaviour at high v. In this regime, the CV response corresponds to a slow electron transfer, of apparent ET rate constant $\mathrm{k}_{\mathrm{ET} \text {,surf }}$, limited by a diffusion process (electron hopping) of apparent diffusion coefficient, $\mathrm{D}_{\mathrm{ap}}$. The variation of $\mathrm{E}_{\mathrm{p}}$ 
with $\mathrm{v}$ is then given by an equation identical with (1), while $\mathrm{i}_{\mathrm{p} \text {,red }}$ is proportional to $\mathrm{v}^{1 / 2}$, according to: ${ }^{38}$

$\mathrm{i}_{\mathrm{p}, \mathrm{red}}=0.496 \mathrm{FAC}_{\mathrm{POM}}^{0}\left(\alpha \mathrm{D}_{\mathrm{ap}} \mathrm{Fv} / \mathrm{RT}\right)^{1 / 2}$

with $\mathrm{C}_{\text {POM }}^{0}$ the volumetric concentration of the POM in the layer of thickness thPOM, $\mathrm{C}_{\mathrm{POM}}^{0}=\Gamma / \mathrm{th}_{\mathrm{POM}}$, and A the electrode surface area. For th ${ }_{\mathrm{POM}}=2.1 \mathrm{~nm}$, the apparent diffusion coefficient characteristic of the charge transfer within the POM layer is $D_{a p}=8 \times 10^{-11} \mathrm{~cm}^{2} \mathrm{~s}^{-1}$. The order of magnitude compares well with that observed for systems of Au nanoclusters which have similar dimensions. ${ }^{60}$ It is also comparable to the charge transport limitation in porphyrin layers, ${ }^{63}$ suggesting the pertinent use of POM layers for molecular electronic devices. If assigned to electron hopping between adjacent immobilized POM centers, then a self-exchange rate constant $\mathrm{k}_{\mathrm{EX}} \sim 5 \times 10^{4} \mathrm{M}^{-1} \mathrm{~s}^{-1}$ is obtained from $\mathrm{D}_{\mathrm{ap}}=\mathrm{k}_{\mathrm{EX}} \mathrm{C}^{0}{ }_{\mathrm{POM}} \delta^{2} / 6,{ }^{50}$ and assuming a redox center distance separation of the order of $\delta \sim 1.5 \mathrm{~nm}$. Meanwhile, $\mathrm{E}_{\mathrm{p} \text {,red }}$ allows the extraction of $\mathrm{k}_{\mathrm{ET} \text {,surf }}=2 \times 10^{-4} \mathrm{~cm} \mathrm{~s}^{-1}$. As for other immobilized systems, the apparent kinetics is much slower than with a dissolved free species $\left(\mathrm{k}_{\mathrm{ET}, \mathrm{sol}}=0.064 \mathrm{~cm} \mathrm{~s}^{-1}\right.$ as determined above).

Finally, if kinetic limitations are manifested when the voltammetric features depart from the fast ET characteristic ( $E_{p, r e d}$ invariant with v), both immobilized and dissolved POMs at glassy carbon electrodes show kinetic limitations for scan rates above $\mathrm{v} \sim 10-30 \mathrm{~V} . \mathrm{s}^{-1}$. It indicates that molecular systems using POM as information storage will respond without delay for frequencies lower than Fv/RT $\sim 1000 \mathrm{~s}^{-1}$. At higher frequencies, different sources of kinetic limitations (electron transfer kinetics, electron hopping and/or counter-ion diffusion) require the injection of more energy in the system for optimized operation. Such kinetic limitation is a drawback when it prevents the selective and sequential injection of electrons in immobilized POM. The selective injection of a single electron in POM requires the application of an electrode potential higher than the onset potential of the second ET system, E>-1.3 V vs SCE. Based on the observed kinetic limitation at immobilized POM, this condition can be met, from (1) for $\mathrm{v}<10^{6} \mathrm{~V} . \mathrm{s}^{-1}$ or frequencies lower than $4 \times 10^{7} \mathrm{~Hz}$, providing a range of operating frequencies more comfortable for the fast molecular memories based on immobilized POMs.

\section{CONCLUSION}

The successful integration of POMs in functional materials for microelectronics or other purposes taking benefit of their remarkable redox properties is dependent on several crucial 
steps, the first two being obviously the choice of the POMs to be assembled and the related method of assembling. Based on our expertise of the functionalization of POMs, we have investigated their covalent anchorage onto surfaces. Starting from the new POM platform $\mathbf{K}_{\mathbf{G e}}[\mathbf{I}]$, which is readily accessible in high yield and purity, $\mathbf{K}_{\mathbf{G e}}\left[\mathbf{N}_{\mathbf{2}}{ }^{+}\right]$and $\mathbf{K}_{\mathbf{G e}}\left[\mathbf{N H}_{\mathbf{2}}\right]$ were prepared. The latter is not only an intermediate in the synthesis of the former but also an interesting precursor to immobilize POMs onto surfaces via peptide-bond formation, as will be reported in a following paper. Post-functionalization of suitable POM-based platforms, such as $\mathbf{K}_{\mathbf{G e}}[\mathbf{I}]$ is a powerful tool to access tailor-made functionalized POMs, in a straightforward way and will deserve further attention. Direct modulation of the organic tether, regarding its nature, length or rigidity is easily achievable and will finally impact the materials properties.

Once prepared, the POM building blocks have to be processed and we have herein described the efficient electrochemical grafting of $\mathbf{K}_{\mathbf{G e}}\left[\mathbf{N}_{2}{ }^{+}\right]$on a glassy carbon electrode. The grafting yields a platform of POM consisting of a dense monolayer, confirmed by RBS, whose charge transfer abilities have been thoroughly characterized.

To our knowledge, the investigation of the degree of communication between the electrode and immobilized POMs is almost absent from literature reports. We have assessed it through the kinetics of electron transfer. The charge transfer process is limited by both the ET kinetic and at higher scan rate by a diffusion process assigned to a hopping mechanism. The kinetic limitation of the overall charge transport has a characteristic rate of the order of $800 \mathrm{~s}^{-1}$. It is difficult to compare to the only other value we have found $\left(25 \mathrm{~s}^{-1}\right)$, since it dealt with another POM structural type and another substrate, namely Linqvist type POM and silicon. ${ }^{23}$ These results on glassy carbon validate our general approach, both from a synthetic and electrochemical point of view, and make us confident to be able to tackle substrates like silicon wafers. Complementary characterization at the solid state is also under current investigation as a step further toward device configuration.

ACKNOWLEDGEMENTS. The authors gratefully acknowledge support from the CNRS and UPMC for a PhD fellowship to $\mathrm{CR}$ and the MiChem Labex for post-doctoral fellowship to SGD. Dr S. Alves is acknowledged for having recorded the mass spectra of the compounds. RBS experiments were performed under the Convention for SAFIR@ALTAÏS between The Université Pierre et Marie Curie and The University of Namur. 
SUPPORTING INFORMATION. ${ }^{1} \mathrm{H}$ and ${ }^{31} \mathrm{P}$ NMR spectra and ESI- spectra for $\mathbf{K}_{\mathrm{Ge}}[\mathbf{I}]$, $\mathbf{K}_{\mathbf{G e}}\left[\mathbf{N}_{3} \mathbf{E} t_{2}\right], \mathbf{K}_{\mathbf{G e}}\left[\mathbf{N H}_{2}\right], \mathbf{K}_{\mathbf{G e}}\left[\mathbf{N}_{\mathbf{2}}{ }^{+}\right]$, cyclic voltammetry of $\mathbf{K}_{\mathbf{G e}}\left[\mathbf{N}_{\mathbf{2}}{ }^{+}\right]$, grafting density by RBS.

\section{REFERENCES}

(1) He, T.; He, J. L.; Lu, M.; Chen, B.; Pang, H.; Reus, W. F.; Nolte, W. M.; Nackashi, D. P.; Franzon, P. D.; Tour, J. M. J Am Chem Soc 2006, 128, 14537.

(2) Sarkar, S.; Suresh, A.; Myers, F. B.; Muth, J. F.; Misra, V. Appl Phys Lett 2008, 92 .

(3) Joachim, C.; Ratner, M. A. P Natl Acad Sci USA 2005, 102, 8801.

(4) Bogani, L.; Wernsdorfer, W. Nat Mater 2008, 7, 179.

(5) Lindsey, J. S.; Bocian, D. F. Accounts Chem Res 2011, 44, 638.

(6) Li, Q. L.; Mathur, G.; Gowda, S.; Surthi, S.; Zhao, Q.; Yu, L. H.; Lindsey, J. S.; Bocian, D. F.; Misra, V. Adv Mater 2004, 16, 133.

(7) Huang, K.; Duclairoir, F.; Pro, T.; Buckley, J.; Marchand, G.; Martinez, E.; Marchon, J. C.; De Salvo, B.; Delapierre, G.; Vinet, F. Chemphyschem 2009, 10, 963.

(8) Proust, A.; Matt, B.; Villanneau, R.; Guillemot, G.; Gouzerh, P.; Izzet, G. Chem Soc Rev 2012, 41, 7605.

(9) Miras, H. N.; Yan, J.; Long, D. L.; Cronin, L. Chem Soc Rev 2012, 41, 7403.

(10) Sadakane, M.; Steckhan, E. Chem. Rev. 1998, 98, 219.

(11) Douvas, A. M.; Makarona, E.; Glezos, N.; Argitis, P.; Mielczarski, J. A.; Mielczarski, E. Acs Nano 2008, 2, 733.

(12) Makarona, E.; Kapetanakis, E.; Velessiotis, D. M.; Douvas, A.; Argitis, P.; Normand, P.; Gotszalk, T.; Woszczyna, M.; Glezos, N. Microelectron Eng 2008, 85, 1399.

(13) Errington, R. J.; Petkar, S. S.; Horrocks, B. R.; Houlton, A.; Lie, L. H.; Patole, S. N. Angew Chem Int Edit 2005, 44, 1254.

(14) Song, Y. F.; McMillan, N.; Long, D. L.; Kane, S.; Malm, J.; Riehle, M. O.; Pradeep, C. P.; Gadegaard, N.; Cronin, L. J Am Chem Soc 2009, 131, 1340.

(15) Joo, N.; Renaudineau, S.; Delapierre, G.; Bidan, G.; Chamoreau, L. M.; Thouvenot, R.; Gouzerh, P.; Proust, A. Chem-Eur J 2010, 16, 5043.

(16) Mercier, D.; Boujday, S.; Annabi, C.; Villanneau, R.; Pradier, C. M.; Proust, A. J Phys Chem C 2012, 116, 13217.

(17) Acronyms used for the POM hybrids: K refers to the Keggin-type anion, Ge as subscript indicates the primary functionalization and the term in brackets corresponds to the pending reactive function.

(18) Pinson, J. in Aryl Diazonium Salts, Wiley-VCH Verlag GmbH \& Co. KGaA 2012, pp. 1.

(19) Allongue, P.; Delamar, M.; Desbat, B.; Fagebaume, O.; Hitmi, R.; Pinson, J.; Savéant, J. M. J. Am. Chem. Soc 1997, 119, 201.

(20) Masheter, A. T.; Wildgoose, G. G.; Crossley, A.; Jones, J. H.; Compton, R. G. J. Mater. Chem. 2007, 17, 3008.

(21) Bouriga, M.; Chehimi, M. M.; Combellas, C.; Decorse, P.; Kanoufi, F.; Deronzier, A.; Pinson, J. Chem. Mater. 2012, 25, 90.

(22) Busson, M.; Berisha, A.; Combellas, C.; Kanoufi, F.; Pinson, J. Chem. Commun. 2011, 47, 12631.

(23) Anariba, F.; DuVall, S. H.; McCreery, R. L. Anal. Chem. 2003, 75, 3837.

(24) Li, Q.; Batchelor-McAuley, C.; N.S. Lawrence; Hartshorne, R.; Compton, R. New J. Chem. 2011, 35, 2462.

(25) Nielsen, L. T.; Vase, K. H.; M. Dong; Besenbacher, F.; Pedersen, S. U.; Daasbjerg, K. J. Am. Chem. Soc 2007, 129, 1888. 
(26) Peng, Z.; Holm, A. H.; Nielsen, L. T.; Pedersen, S. U.; Daasbjerg, K. Chem. Mater. 2008, 129, 6068.

(27) Combellas, C.; Kanoufi, F.; Pinson, J.; Podvorica, F. I. J. Am. Chem. Soc 2008, $130,8576$.

(28) Combellas, C.; Jiang, D.-e.; Kanoufi, F.; Pinson, J.; Podvorica, F. I. Langmuir 2009, 25, 286.

(29) Leroux, Y. R.; Fei, H.; Noel, J. M.; Roux, C.; Hapiot, P. J Am Chem Soc 2010, $132,14039$.

(30) Souchay, P. 1963.

(31) Dangles, O.; Guibe, F.; Balavoine, G.; Lavielle, S.; Marquet, A. J Org Chem 1987, 52, 4984.

(32) Li, G. R.; Wang, X. H.; Li, J.; Zhao, X. J.; Wang, F. S. Tetrahedron 2006, 62, 2576.

(33) Matt, B.; Moussa, J.; Chamoreau, L. M.; Afonso, C.; Proust, A.; Amouri, H.; Izzet, G. Organometallics 2012, 31, 35 .

(34) Lu, M.; Nolte, W. A.; He, T.; Corley, D. A.; Tour, J. M. Chem Mater 2009, 21, 442.

(35) Smith, M. B.; March, J. in March's Advanced Organic Chemistry WileyInterscience, New York, 2001, 816.

(36) Himeno, S.; Takamoto, M. J Electroanal Chem 2002, 528, 170.

(37) J. Zhang, A. M. B., D.R. MacFarlane, S.A. Forsyth, J.M. Pringle, A.W.A. Mariotti, A.F. Glowinski, A.G. Wedd Inorg Chem 2005, 44, 5123.

(38) A. J. Bard, L. R. F. Electrochemical Methods: Fundamentals and Applications, 2nd Ed., Wiley, New York, 2001.

(39) S. W. Feldberg, I. R. J. Electroanal. Chem. 1988, $240,1$.

(40) C. Amatore, E. M., B. Schöllhorn, J. Wadhawan Chemphyschem 2007, 8, 1321.

(41) M. A. Ghanem, J.-M. C., A. Pinczewska, J. D. Kilburn, P. N. Bartlett J. Mater. Chem. 2008, 18, 4917.

(42) Forster, R. J.; Faulkner, L. R. J. Am. Chem. Soc 1994, 116, 5444.

(43) Gambardella, A. A.; Feldberg, S. W.; Murray, R. W. J. Am. Chem. Soc 2012, $134,5774$.

(44) Ren, X. M.; Pickup, P. G. 1993, 97, 5356.

(45) Huang, W. L.; Todaro, L.; Yap, G. P. A.; Beer, R.; Francesconi, L. C.; Polenova, T. J Am Chem Soc 2004, 126, 11564.

(46) Based on a hexagonal close packed lattice, the surface occupied by a single sphere is $1.44^{2} \times 1 / 2 \times\left(3^{\wedge} 1 / 2\right)$

(47) Brooksby, P. A.; Downard, A. J. Langmuir 2004, 20, 5038.

(48) Laviron, E. J. Electroanal. Chem. 1979, 101, 19.

(49) Savéant, J. M. Elements of Molecular and Biomolecular Electrochemistry, Wiley, Hoboken 2006.

(50) C. P. Andrieux, J.-M. S. J. Electroanal. Chem. 1980, 111, 377.

(51) Laviron, E. J. Electroanal. Chem. 1980, 112, 1.

(52) D. N. Blauch, J. M. S. J. Am. Chem. Soc 1992, 114, 3323.

(53) D. Lee, J. C. H., A. M. Leone, J. M. DeSimone, R.W. Murray J. Am. Chem. Soc 2002, 124, 9310.

(54) W. Wang, D. L., R.W. Murray J. Phys. Chem. B 2006, 110, 10258.

(55) C. Amatore, Y. B., E. Maisonhaute, J.I. Goldsmith, H. D. Abruna Chemphyschem 2001, 2, 1439.

(56) T. Morita, S. K. J. Am. Chem. Soc. 2003, 125, 8732.

(57) F. Hauquier, J. G., B. Fabre, P. Hapiot J. Am. Chem. Soc 2008, 130, 2748. 
(58) Q. Wang, S. M. Z., Md.K. Nazeeruddin, R. Humphry-Baker, M. Grätzel J. Am. Chem. Soc 2006, 128, 4446.

(59) D. Lee, R. L. D., J. M. DeSimone, R.W. Murray J. Am. Chem. Soc 2003, 125, 1182.

(60) Kim, J.; Lee, D. J. Am. Chem. Soc 2006, 128, 4518.

(61) K. Aoki, T. T., H. Matsuda J. Electroanal. Chem. 1983, 146, 417.

(62) K. Aoki, K. T., H. Matsuda J. Electroanal. Chem. 1984, 160, 33.

(63) Savenije, T. J.; Koehorst, R. B. M.; Schaafsma, T. J. J. Phys. Chem. B 1997, 101,720 . 
Scheme 1. Synthetic routes to the diazonium-terminated hybrid $\mathbf{K}_{\mathbf{G e}}\left[\mathbf{N}_{2}{ }^{+}\right]$

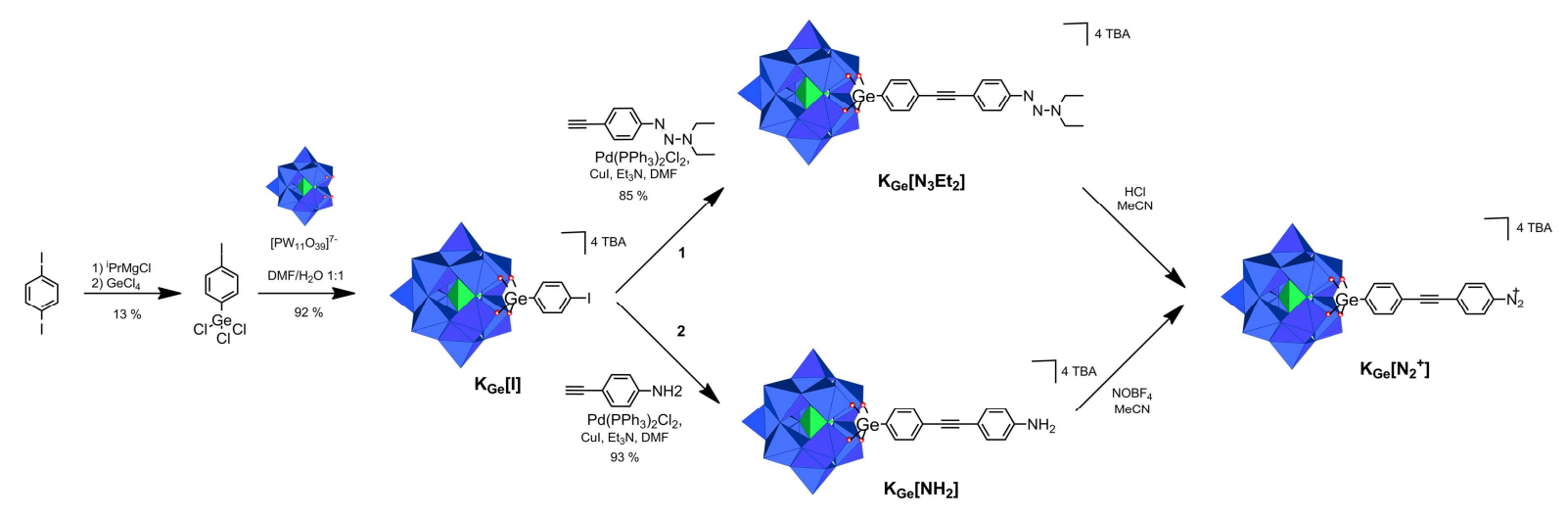




\section{Figure captions}

Figure 1. ${ }^{1} \mathrm{H}$ NMR monitoring of the formation of the diazonium-derived hybrid $\mathrm{K}_{\mathrm{Ge}}\left[\mathrm{N}_{2}{ }^{+}\right]$ from $\mathrm{K}_{\mathrm{Ge}}\left[\mathrm{N}_{3} \mathrm{Et}_{2}\right]$

Figure 2. a) Cyclic voltammetry at a glassy carbon electrode (2 $\mathrm{mm}$ diameter) of $\mathbf{K}_{\mathbf{G e}}[\mathbf{I}]$ (1

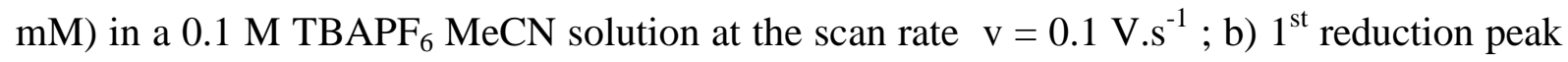
potential variation with v. Symbols: experimental values, lines: predicted variations, see text.

Figure 3. a-d) Cyclic voltammetry of the $\mathbf{K}_{\mathbf{G e}}$-grafted glassy carbon electrode $(2 \mathrm{~mm}$ diameter) in a $0.1 \mathrm{M} \mathrm{TBAPF} \mathrm{MeCN}_{6}$ solution ; a) scan rate, $\mathrm{v}=0.1 \mathrm{~V}^{-1}{ }^{-1}$; b) $\mathrm{v}=1,5,20,50$, 100, 250 and $500 \mathrm{~V} . \mathrm{s}^{-1} ; 1^{\text {st }}$ peak c) current and d) potential variation with v. Symbols: experimental values, lines: predicted variations, see text. 
Figure 1
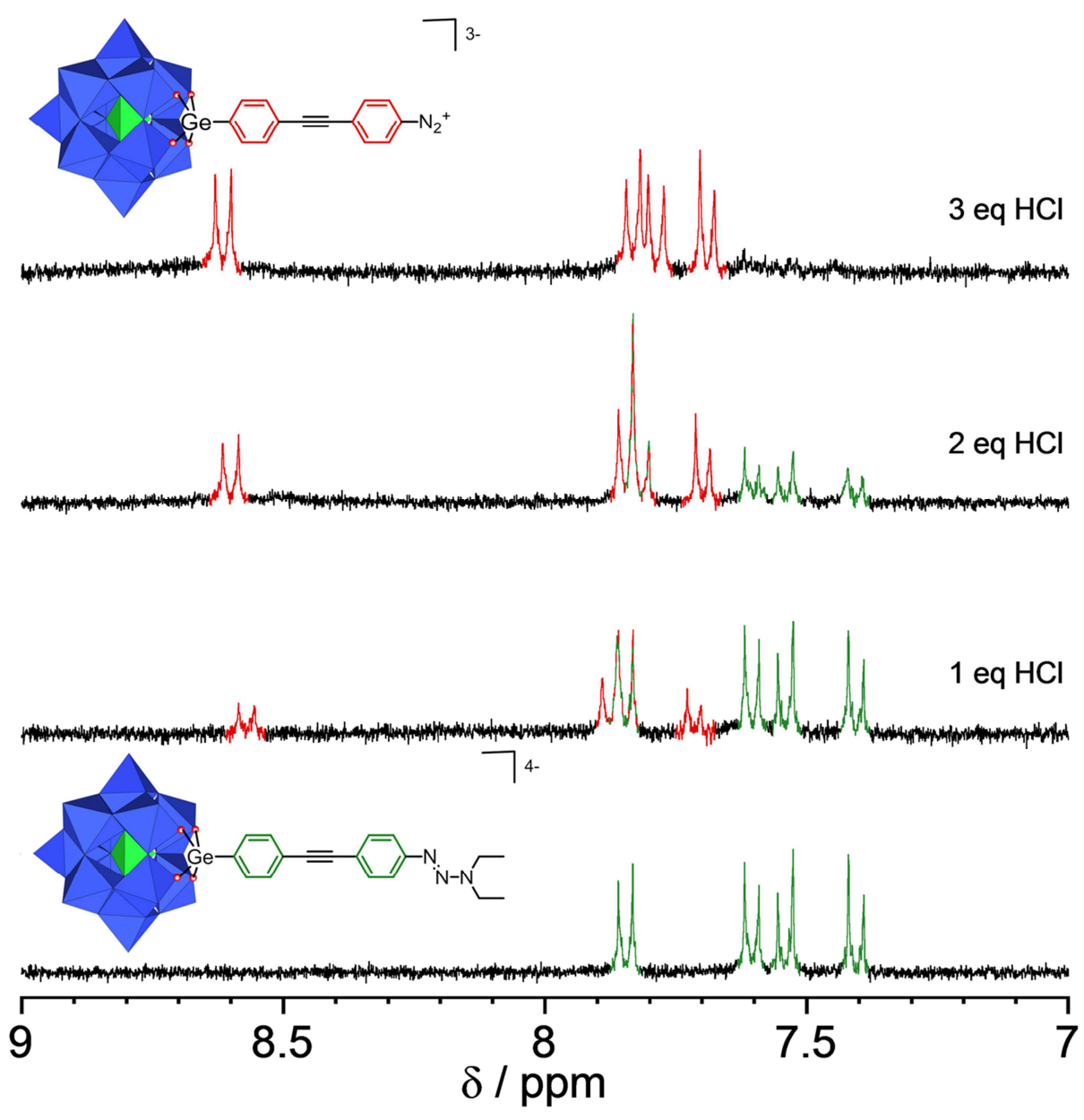
Figure 2

a)

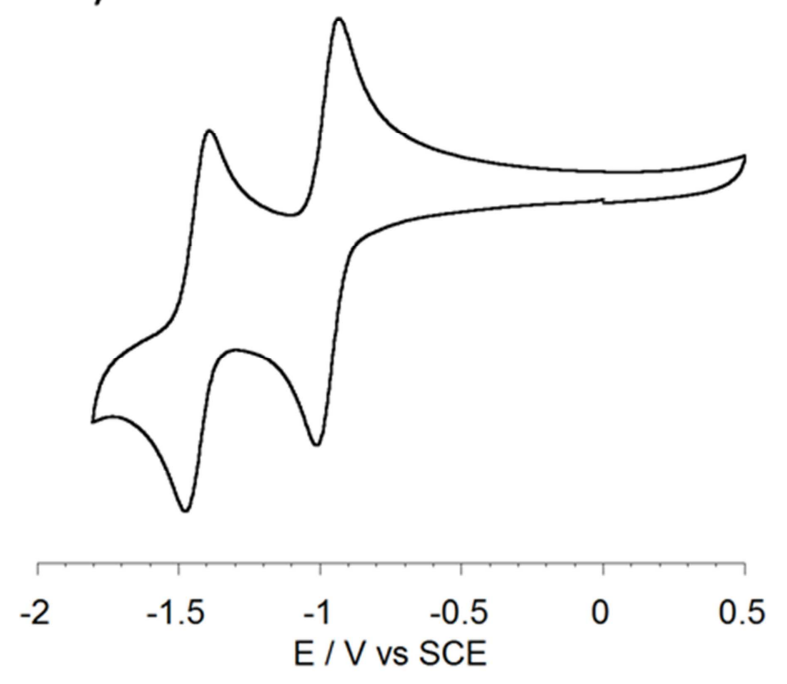

b)

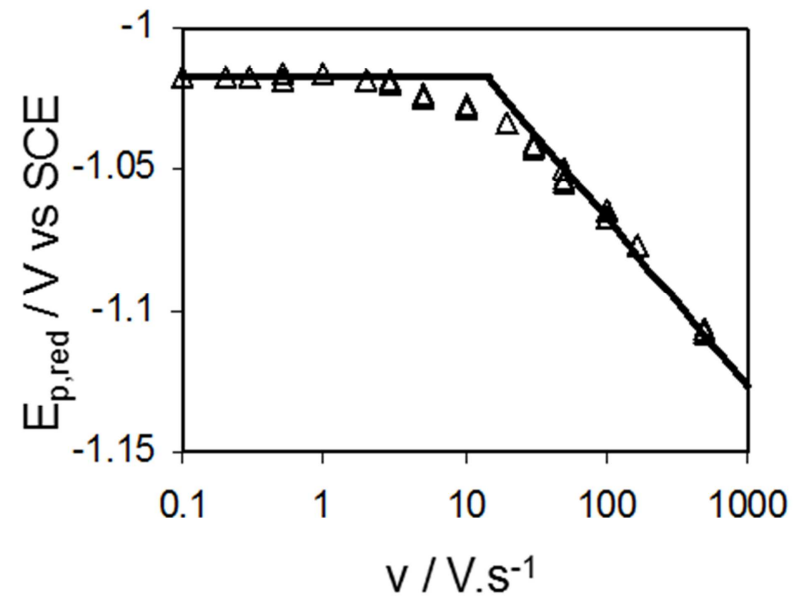


Figure 3

a)

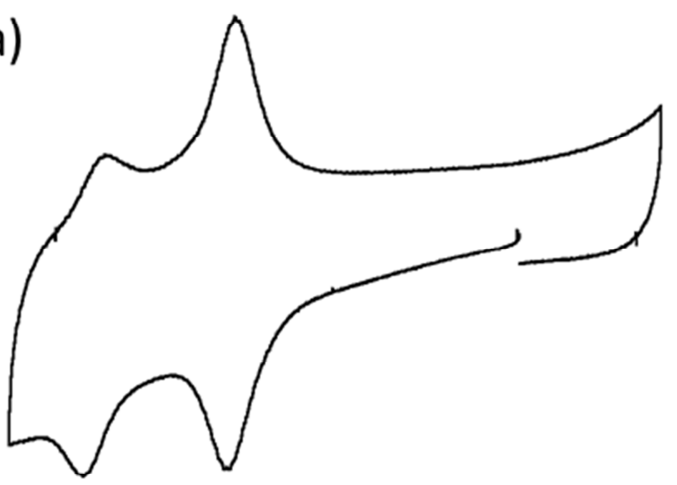

$\begin{array}{llllll}-2 & -1.5 & -1 & -0.5 & 0 & 0.5\end{array}$ E / V vs SCE

c)

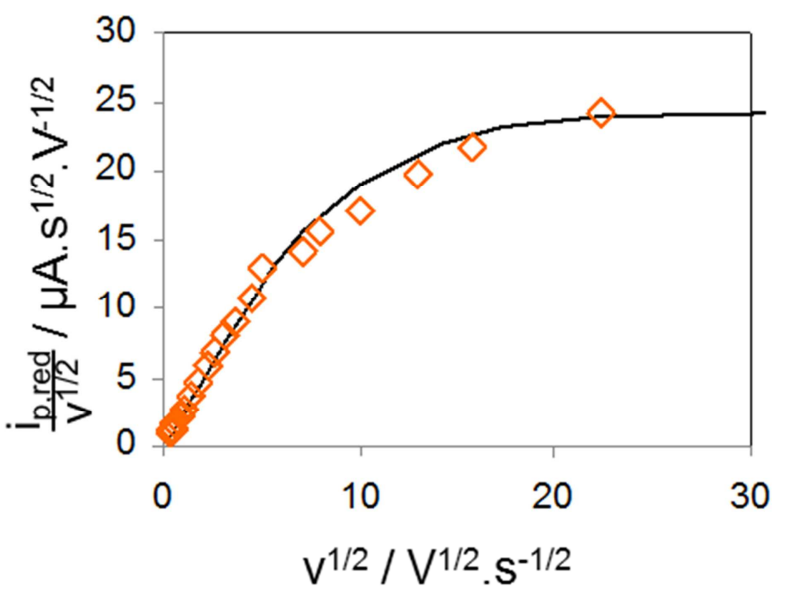

b)

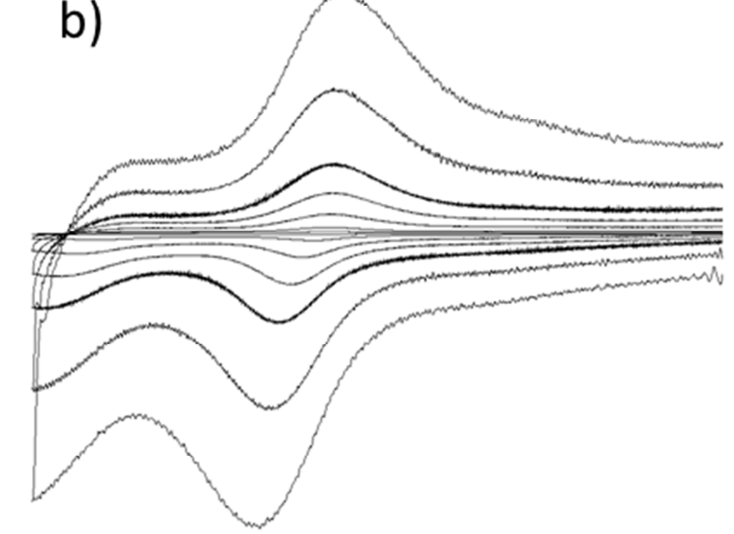

$-1.6 \quad-1.2 \quad-0.8$

E / V vs SCE

d)

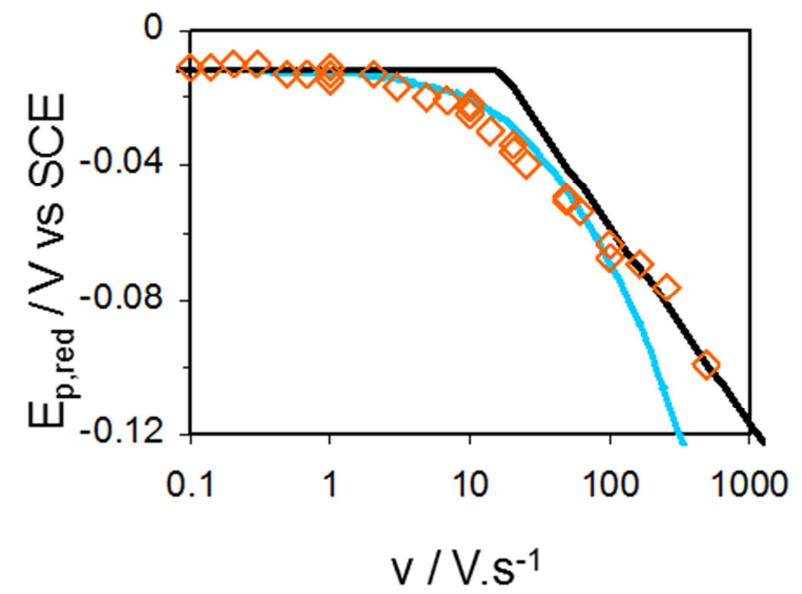


TOC

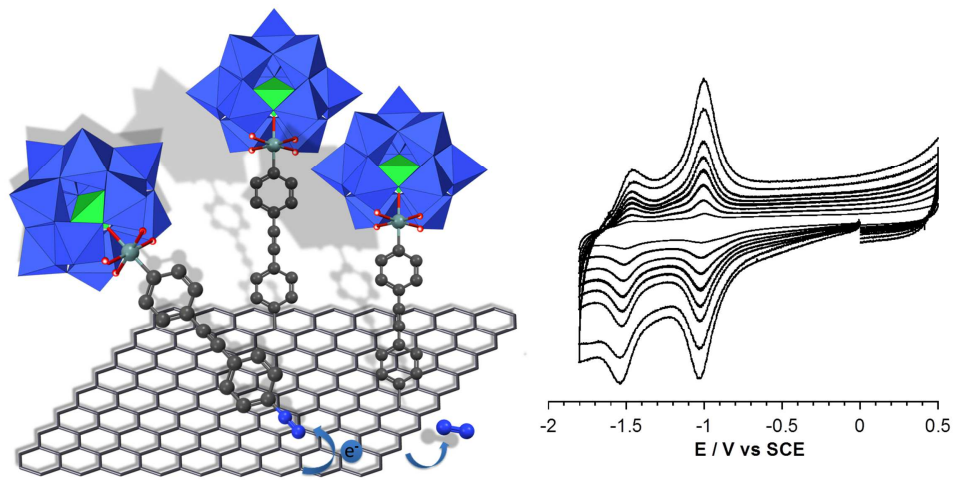

